\title{
Testing the Design and Implementation of Teaching Materials Developed for Writing Budget Reports Using Microsoft Excel Media
}

\author{
Ni Luh Gede Erni Sulindawati ${ }^{*}$ \\ ${ }^{1}$ Economics and Accounting Department, Universitas Pendidikan Ganesha, Singaraja, Indonesia \\ e-mail: mailto:esulind@gmail.com
}

\begin{abstract}
This study was conducted to find out the result of testing the design and implementation of teaching materials developed for writing budget reports using Microsoft Excel media. The study method used teaching material development that consists of the steps of (1) design validation, (2) design revision, (3) product try-out, (4) product revision, and (5) use try-out. The design validation was done by asking experts to evaluate the design. The materials developed were in the form of syllabus, semester lesson plans, learning materials that contain practice problems, and worksheets, and assessment rubric. The subjects were students who enrolled in Budgeting Course. The instruments used were observation guide, interview guide, questionnaire, and learning achievement test. The data were analyzed by using descriptive analysis by measuring the students' learning achievement as shown in their scores in the process of learning to write budget reports. The evaluation was done based on the scores the students got from the process evaluation, attitude and participation, and tasks as well as from the product evaluation as shown by the products written by the students. The result of the experts' judgment of the design showed that the design is very valid. The implementation showed that the students' learning achievement in writing budget reports using Microsoft Excel showed that the mean scores for attitude, participation, product evaluation can be categorized into the very good category. Hence, these teaching materials can be used in the teaching process for teaching how to write budget reports.
\end{abstract}

Keywords: Teaching Materials; Budget Report; Microsoft Excel

\section{Introduction}

There are many studies related to the budget such as (1) budget planning, budget control, business age, and financial performance in small businesses (Foster, 2017), (2) a collaborative approach to budgeting and the impact on the budgeting process: a case study, (Roestel, 2016), (3) antecedents of participative budgeting (Shields \& Shields, 1998), (4) procedural justice in the relationship between budgetary goal characteristics and managerial performance of government officials (Bawono, 2008), an analysis of municipal budget variances (Giroux, 1991). Research on the foundation budget is more examining the effect of the budget on the performance of companies or government agencies but has not discussed how that can be done to facilitate understanding in preparing budget reports.

This paper is a continuation of an article made earlier on An Analysis Of Learning Devices Needing In Budget Reporting, where problems that occur in learning related to budget preparation are encountered in the field during the learning process, students experience difficulties in terms of mastery and understanding of the process comprehensive budgeting. In the previous research, it is known that the obstacles faced by students in implementing learning in the budgeting course (1) have not comprehensively understood the steps in preparing a budget, especially in the procedure of preparing a sales budget that requires data and information from several competent sources, (2) do not understand the format or presentation of the budget report specifically the cash budget properly, and (3) have not been able to fully practice how to prepare a budget properly (Sulindawati, Yudantara, \& Musmini, 2019).

Accounting graduates in general can work in various business activities and can also open business opportunities or entrepreneurship. To be able to compete in the world of work

\footnotetext{
* Corresponding author.

Received 23 April 2020; Accepted 16 June 2020; Available online 20 June 2020

(C) 2020 JPI. All Rights Reserved
} 
and business, accounting majors students are equipped with various competencies. The graduates of the Accounting Study Program have among others are competencies in accounting management In the accounting management course, the budget report is the important thing that needs to be understood. The budget report is a report about the realization of the implementation of the budget that is completed with a comparative analysis between budget and its realization so that deviations that might have occurred can be identified, both positive deviations (that are profitable) and negative deviations (that are not profitable (Munandar, 2001). To acquire expertise in managerial accounting, the students are required to understand the basic concepts of total budgeting system and to be able to write a total budget, production budget, raw material budget, manpower budget, overhead cost budget, general administration cost budget, capital budgeting, cash budget, a projection of a financial report budget and budget analysis (Sulindawati, Yudantara, et al., 2019). The total budget system has a long process that starts with the writing of production budget, raw material budget, manpower budget, overhead cost budget, general administration cost budget, capital budgeting, and cash budget both for the service, trade, manufacturing corporations in the private and the government sectors (Sulindawati, Yudantara, et al., 2019).

The reality in the class during the learning process various complex problems arise, students encounter difficulties in terms of mastery and understanding of the overall budget preparation process. Understanding the concepts in preparing financial budgets requires more ability from students. To facilitate the understanding of students in the process of preparing a budget, it is necessary to be assisted with appropriate learning tools and media, especially in preparing budget reports.

The media that can be used in writing budgets is the Microsoft Excel program that is suitable for the program that is going to be used by a corporation (Sulindawati, Yudantara, et al., 2019). Microsoft Excel can be used to process data quickly consisting of many sheets that can be changed as needed (Sulindawati, Suharsono, Lasmawan, Natajaya, \& Sunu, 2019). Microsoft Excel media in developing the budget that has been developed is expected to be used in learning. The purpose of this paper is to analyze the learning media that have been developed. From the background description, it can be proposed the problem formula whether the learning device in preparing the budget report through the Microsoft Excel media that was developed is valid as a learning resource to improve student competency in preparing the budget. The validity of the design of teaching materials in writing budget reports to be developed needs to be analyzed and tried out. This writing aims to analyze whether the design of the teaching materials can be used in the teaching process.

\section{Method}

The teaching materials design can follow four stages based on the ADDIE Review development model by experts in the study outside the instructional development, one by one try-out, small group try-out and field try-out (Adha, 2012), (Widyaningsih, Yusuf, Prasetyo, \& Istiyono, 2020). In this study the teaching materials design was tested through the stages of (1) design validation, (2) design revision, (3) product try-out, (4) product revision, and (5) use try-out. The instruments used were questionnaires, observation sheets, interview guide sheets, process learning achievement processes, and product learning achievement test a limited try-out and broad-scale try-out (Adha, 2012).

The data that came from the monitoring instrument and model effective evaluation were analyzed using percentage quantitative approach (Adha, 2012) the data coming from an in-depth interview and participative observation were analyzed using the approach developed by Miles and Huberman covering the steps of 1). Data collection: collecting all data; 2) data classification; 3 ) data reduction: the process of data reduction or data selection to obtain data that are valid and suitable with the result of data triangulation; 4) concluding: this process is done by referring to valid data (Adha, 2012).

The design of these teaching materials was validated by three experts and tried out in a small group consisting of 10 students of a class of 20 students who learned budgeting course. In this study, the teaching materials developed were in the form of syllabus, 
semester lesson plans, teaching material that contains Practice Problems and Worksheet, and evaluation rubric. The data were collected through observation, test, and questionnaire, the data were collected by using instruments which consisted of expert's validation sheet, semester lesson plan implementation observation sheet, student's response sheet concerning the results of the evaluation of the process, attitude, and participation, the results of the evaluation of task process mid-semester product test, end of semester product test (Undiksha, 2017).

The techniques of data analysis used consisted of Expert's validation analysis, The analysis of semester lesson plan implementation, analysis of student responses, and analysis of Learning Outcomes (1) Expert's validation analysis done by a. counting the validity score from expert's validation results using the formula: validity $(V)=$ total score of the validation results from 3 experts divided by maximal total score $\times 100 \%$ (Fatmawati, 2016). The result of validity whose percentage has been found out can be matched with the validity criteria as presented in Table 1.

Table 1. The criterion of the Validity of Teaching Materials

\begin{tabular}{ccc}
\hline No & Score & Criterion of Validity \\
\hline 1 & $85.01-100.00 \%$ & Very valid \\
2 & $70.01-85.00 \%$ & Valid enough \\
3 & $50.01-70.00 \%$ & Less valid \\
4 & $01.00-50.00 \%$ & Not valid \\
\hline & & Source : Akbar, 2013)
\end{tabular}

(2) The analysis of semester lesson plan implementation was done by counting using the formula: total score obtained divided by the number of items evaluated. Then, the obtained value is categorized into very poor (scores 0-1.5), poor (scores 1.6-2.5) good (score 2.6-3.5), very good (score 3.6-4.00) (Fatmawati, 2016); (3) "The analysis of student's response was done by using Likert scale. Every item of questions was given a score and its number was counted, then its percentage was counted. The closer it was to $100 \%$ the student's response became more positive toward the teaching (Fatmawati, 2016). The assignment of the score for the Likert scaled questionnaire between positive and negative statements is shown in Table 2.

Table 2. System of Response Questionnaire

\begin{tabular}{clcccc}
\hline No & Attitude Statement & SA & A & D & SD \\
\hline 1 & Positive Statement & 5 & 4 & 2 & 1 \\
2 & Negative Statement & 1 & 2 & 4 & 5 \\
\hline
\end{tabular}

Source : (Arikunto, 2013; Fatmawati, 2016).

The student's response was seen from the easy the student understood the material and teaching media and its attractiveness and whether the teaching process was systematical or not. (4) The analysis of Learning Outcomes consists of the analysis of Learning Achievement concerning Process, Attitude and Participation, the result of process evaluation, mid-semester test product evaluation and student's end of semester test evaluation by a calculation using the formula "Percentage of learning achievement score = score obtained divided by maximal score $\times 100 \%$, Then, the percentage was categorized as high $(76-100 \%)$, medium $(56-75 \%)$, low $(40-55 \%)$, and very low $(<40 \%)$ (Arikunto, 2010; Fatmawati, 2016).

\section{Results and Discussion}

3.1. Result

The results of the design for developing teaching materials for writing budget reports using Microsoft media are in the form of syllabus, semester lesson plans, learning materials that contain practice problems, worksheets, and evaluation rubric. The testing of this design 
was done by the following four stages: experts' review, limited try-out, and classroom try-out. The experts' review was done by three lecturers of budgeting course and was done through a Focus Group discussion (FGD). The FGD result showed the result of the tabulation of scores given by the experts, which can be seen in Table 3 .

Table 3. Results of Validation Tabulation

\begin{tabular}{clcc}
\hline No & \multicolumn{1}{c}{ Teaching Materials } & Mean & Criteria \\
\hline 1 & Syllabus & 86.00 & Very Valid \\
2 & Semester Lesson Plans & 88.33 & Very Valid \\
3 & Learning Material & 86.00 & Very Valid \\
4 & Practice Problems & 86.33 & Very Valid \\
5 & Worksheet & 86.67 & Very Valid \\
6 & Evaluation Rubric & 86.00 & Very Valid \\
\hline
\end{tabular}

Table 3 shows that the validation of the teaching materials falls into the very valid category. However, there were still some inputs from the experts concerning the learning material that needs to be added for the writing of budgets for the nonprofit organizations, and this, therefore, is related to worksheet an evaluation rubric. After revising, the teaching materials need to be subjected to a product try-out. The try-out was done in a small group and a one-class try-out. The stages of teaching activities done conformed to the semester lesson plans that had been validated by media experts. The result of the (Mahirah, Djuwairiah, \& Sukirman, 2016) small group try-out, small class, and whole-class try-outs can be seen in tables 4 and 5 below.

Table 4. The Result of Small Group Try-out

\begin{tabular}{clcc}
\hline No & \multicolumn{1}{c}{ Aspects Evaluated } & Mean & Criteria \\
\hline 1 & Semester Lesson Plans Implementation & 3.5 & Very good \\
2 & Students' Response & $86.00 \%$ & Very Good Positive \\
3 & Result of Process, Attitude and Participation Evaluations & $85.00 \%$ & Very good \\
4 & Result of Task Process Evaluation & $86.00 \%$ & Very good \\
5 & Mid Semester Test Product Evaluation & $85.00 \%$ & Very good \\
6 & End of Semester Test Product Evaluation & $83.00 \%$ & Good \\
\hline
\end{tabular}

From table 4 of the result of the small group try-out of the teaching materials it is seen that the students' response is close to the very good criterion, but "at the end of semester test product evaluation (Westin, Sundler, \& Berglund, 2015), it still falls into good criterion $(83 \%)$, just the problems of the end of the semester is still needs to be improved.

Table 5. Result of in the Classroom Try-out

\begin{tabular}{clcc}
\hline No & Aspects Evaluated & Mean & Criteria \\
\hline 1 & Semester Lesson Plans Implementation & 3.6 & Very good \\
2 & Students' Response & $88.18 \%$ & Very good (+) \\
3 & Result of Process, Attitude and Participation Evaluations & $85.00 \%$ & Very good \\
4 & Result of Task Process Evaluation & $86.20 \%$ & Very good \\
5 & Mid Semester Test Product Evaluation & $87.73 \%$ & Very good \\
6 & End of Semester Test Product Evaluation & $85.50 \%$ & Very good \\
\hline
\end{tabular}

From table 5 it can be seen that the mean score of the teaching materials falls into a very good criterion, and there was an increase in score in each aspect of evaluation. 


\subsection{Discussion}

From the results of the research described previously, it can be seen that the development of learning tools for preparing budget reports using Microsoft Excel media from the results of the validation tabulation is classified as very valid means that the learning tools developed can be continued with trials. Microsoft Excel was developed in the writing of budget reports. Microsoft Excel can be used in the teaching process in the teaching and educational processes that suit the following expert's opinion.

Microsoft Excel is one of the computer programs that all offices and educational institutions use. With the presence of Microsoft Excel, the work of managing and calculating data will become much easier and can be done quickly with accurate and maximal results (Hasanah, 2019). Microsoft Excel is one of the software products for data processing in the form of table sheets that are spread (spreadsheets). This software is part of many soft wares (office requirements) for example Microsoft Excel was used for processing various types of data for example student's scores which mean types of numeric data, friend's data and students' scores, which means the data belongs to text data type, the data on the recapitulation of the use of goods in the form of number and text, etc. In Excel, in addition, to be able to use for recording and storing the data, Excel can also do the calculation, In excel, besides being able to be used for recording and saving the data, Excel can also do the counting, do addition, multiplication, logical functions, the counting of mean scores, addition, multiplication, the computation of addition, multiplication, logical functioning, the mean scores, and even the drawing of graphics (Stafnew, 2018; Sulindawati, Suharsono, et al., 2019).

The process of writing a budget report starts by determining (1) the prediction of sales for the industrial business that contains titles of production goods, units, prices, and the total number of sales. This sale budget can be made by using the existing table in sheet Microsoft excel, (2) then, it is continued by writing production budgets, which can be written in the second sheet of the Microsoft Excel in the form of (Wright \& Nelsen, 2019) table which contains a period, sale rate, final inventory, initial inventory, and production rate (Wright \& Nelsen, 2019), (3) the next step is to write the raw material budget. This raw material budget is written as the planning of the number of raw material needed for production in the coming period.

The budget of raw material need is written for planning the number of raw physical materials needed, not its value in rupiah. Specifically, in this budget is stated the type of finished product that will be produced, types of raw material used. The following parts have to be passed in production. Standard usage rate SUR. SUR is a quantity that shows how many units the raw material is needed to produce a unit of the finished product (Savitri, 2018), (4) Budget for the purchase of raw material. This budget is written as the planning of the quantity of raw material that "has to be purchased in the coming period (Physicscatalyst, 2019). "This has to be done (Physicscatalyst, 2019) carefully, especially concerning the quantity of purchase and time of purchase (Wikipedia, 2013). In purchasing raw material one has to take into account the quantity of purchase and time of purchase and also the inventory and raw material need factors. The number of purchase that is most economical (Economical Order Quantity/ EOQ).

$E O Q$ is a volume or number of the most economical purchase to be done at every time of purchase. This model can be used both for purchased goods and goods produced by oneself (Nasution \& Prasetyawan, 2008; Suryanto \& Sadjiarto, 2013). It is the number of direct goods that have to be purchased at every time the purchase is "made so that it will be" (Context, 2019) purchased at the lowest cost, but will not cause scarcity of direct raw material. (5) In the next sheet a manpower cost budget, overhead cost budget, cash budget, liabilities budget, profit-loss budget, and balance budget are written.

After the teacher presented the learning material to the students, the teacher gave a task to write budget reports for various economical entities, both profit and nonprofit using Microsoft Excel. For nonprofit corporations (Lpdirect, 2019), or nonprofit organizations the attainment of objectives is not measured in financial terms but more in the usefulness of the organization for the community that needs help from the nonprofit organization (Wikipedia, 
2018). The nonprofit organizations can be grouped into two major categories: those that need overhead capital and then self-finance themselves, the second category is the nonprofit organizations that are supported by regular support or financial aid, not by selling a certain service. This group includes the central government and local government, supported by the income from taxes, interest rates, fundraising, other obligations, etc. mostly by force, included in this group are those that get finance not by force or people donate their money voluntarily, for example, social organizations, orphanages, and the like (Suryono, 2016).

A nonprofit organization, according to Wikipedia is an organization that aims at supporting an issue or course in attracting public attention to a noncommercial objective, without any concern with things that are profit-seeking (monetary) nonprofit organizations cover the church, public school, public charity, hospital, public clinic, political organization, community aids in the case of laws and regulations, volunteer service organization, labor union, professional association, research institute, museum, and some government officials (Haryani \& Pranoto, 2012; Wikipedia, 2018). On the other hand, the profit organizations are organizations aimed at making a profit from the money spent, especially that which comes from profits (Wikipedia, 2018).

To get responses from the students, an interview was also conducted about the design of the teaching (Parliament, 2018) and the process that had been implemented. From the interview, it was found out that the students' opinions about the teaching media developed that the media are easy and systematical to be used so that the students' understanding of the process of writing budget reports increased.

At every classroom meeting, the researcher observed the attitudes and participation of the students in every teaching and learning process. In the eighth week and the sixteenth week, a test was administered to evaluate the students' learning achievement and their responses by distributing questionnaires (Mahirah et al., 2016). This learning device was tested in small groups and one class. trials of learning tools in small groups are almost classified as very good, but in the assessment of the products, the Final Examination Semester is still relatively good so that results in the final examination product are still improved. With this excel learning media the implementation of the semester learning plan runs according to the specified time, positive student responses which means learning with this media is practically fun and easy to use. The results of the Attitude and Participation Process Assessment are very good as seen from the attitudes and participation of students in active learning, namely students actively asking questions and doing assignments diligently. The results of the assignment assessment, midterm examination products, excellent end of semester examination products can be seen from working on time, accuracy in calculating numbers, the accuracy of steps in preparing the budget report, and matching the appearance of the resulting product. The use of Microsoft Excel media in learning is very useful in facilitating students to understand how to prepare budget reports properly.

Other research related to technology carried out by Haliza binti Mohd Said, the research findings show that perceived usefulness, perceived ease of use, enjoyment and self-efficacy computers have a significant relationship to the behavioral intentions of employees to use online technology applications in their workplaces (Said, Baharudin, Izharuddin, Idris, \& Othman, 2019). The other research is Nguyen Van Thuy's research which obtained evidence that the perceived benefit factor has the strongest impact on intention to use technology, the next factor is social influence, and perceived ease of use affects user intentions, (Thuya, 2020). Furthermore, Oanh Thi Tu Leam's research found that perceived benefits and perceived ease of use have a positive impact on a company's intention to use cloud-based accounting software (Thi, Le, \& Mai, 2020).

This is following the theory of accepted model technology which states that the technology can be accepted by users if the technology meets the elements of usefulness and ease of use (Venkatesh, Morris, Davis, \& Davis, 2003). The use of this media is also following the theory of the Unified Theory of Acceptance and Use of Technology integrated model developed by Venkatesh et al (2003) based on a social cognitive theory with a combination of eight leading research models regarding the acceptance of information 
technology (Ahmad, Shaari, Hussin, Tajudin, \& Hansaram, 2019; Venkatesh, Thong, \& Xu, 2012; Venkatesh \& Zhang, 2010).

The use of technology to be used should also consider the risks associated with technology. These risks can be in the form of costs arising from the use of technology. Costs incurred from using the technology must be lower than the benefits derived from the use of technology. In the development of learning tools in preparing budget reports through Microsoft Excel media, the costs used are very small compared to the benefits obtained by users, namely ease, savings in understanding in preparing budget reports.

\subsection{Implications Learning Tools In Preparing Budget Reports Through Microsoft Excel Media}

Learning tools in preparing budget reports through Microsoft Excel media that have been developed have a positive contribution given to the world of education, especially in preparing competent personnel in the field of accounting, especially in the field of budgeting as a tool for planning, implementing and monitoring a business activity, which can combine developments science with technological developments.

The rapid development of science and technology has demanded the ability of professional lecturers to produce graduates who are ready to use and able to adapt to the technological developments that occur. Learning activities in higher education institutions are not only focused on efforts to obtain as much knowledge in theory as possible but must also be able to take advantage of technological developments to improve the quality of learning. Improving the quality of learning is expected to be able to create professional skills in certain fields that are very important for students and their future. This learning tool can contribute to completing various learning tools and media needed in lectures in the economics and accounting majors. The resulting product can overcome the limitations of learning media about the combination of the development of accounting science based on information obtained from various technology sources, especially Microsoft Excel-based technology.

The realization of this learning media will be able to create an exciting learning atmosphere and conditions by bringing the situation closer to the real conditions that occur in the business world so that the ability to think critically and tactically from students can be improved. Increased critical and tactical thinking skills affect the availability of a reliable human workforce. With the results of a very valid validity test, this learning tool will also be able to be used in the learning process at other educational institutions.

\section{Conclusion and Suggestions}

The results of validation, from the experts, and the try-outs of the teaching materials for writing budget reports using Microsoft Excel media which consist of Semester Lesson Plans Implementation, Results of Process, Attitude and Participation Evaluation, Results of Task Process. Mid Semester Product Evaluation and End of Semester Test Product Evaluation falls into a very valid criterion, and from the results of the classroom try-out, the score falls into a very good criterion. With these results, we can say that the teaching materials for writing budget reports can be used as one of the learning media for budgeting courses, especially in writing budget reports.

\section{References}

Adha, M. M. (2012). Model Pengembangan Pembelajaran Pendididikan Kewarganegaraan Berbasis Multikultur Dalam Rangka Menanamkan Nilai-Nilai HAM dan Demokrasi. Jurnal Media Komunikasi FIS, 12, 1-16.

Ahmad, S. N. B., Shaari, A., Hussin, H., Tajudin, M. M., \& Hansaram, S. kaur. (2019). Influence of perceived risk on consumer attitude and repurchase intention among gen $Y$ online shoppers in Malaysian. International Journal of Innovation, Creativity and Change, 6(4), 42-54.

Akbar, S. (2013). Instrumen Perangkat Pembelajaran. Bandung: Remaja Rosdakarya.

Arikunto, S. (2010). Prosedur Penelitian: Suatu Pendekatan Praktik. Jakarta: Rineka Cipta.

Arikunto, S. (2013). Dasar-Dasar Evaluasi. Jakarta: Rineka Cipta. 
Bawono, A. D. B. (2008). Keadilan Prosedural dalam Hubungan Antara Budgetary Goal Characteristics dan Kinerja Manajerial Pejabat Pemerintah. Jurnal Akuntansi Dan Keuangan, 7(2), 151-161.

Context, R. (2019). context.reverso,https://context.reverso.net/translation/englishrussian/so+that+it+will+be\%26amp\%3Bved\%3D2ahUKEwjVmZ3onJDkAhUg63MBHY bCCE8QFjAAegQIBBAB. Retrieved from http://context.reverso.net/traducao/inglesportugues/smart

Fatmawati, A. (2016). Pengembangan Perangkat Pembelajaran Konsep Pencemaran Lingkungan Menggunakan Model Pembelajaran Berdasarkan Masalah Untuk Sma Kelas X. EduSains, 4(2), 10. Retrieved from file://C:/Users/asus/Downloads/59351-IDpengembangan-perangkat-pembelajaran-kons.pdf

Foster, T. A. (2017). Budget Planning, Budget Control, Business Age, and Financial Performance in Small Businesses. ProQuest Dissertations and Theses, 123. Retrieved from

https://search.proquest.com/docview/1893566165?accountid=26642\%0Ahttp://link.peri odicos.capes.gov.br/sfxlcl41?url_ver=Z39.88-

2004\&rft_val_fmt=info:ofi/fmt:kev:mtx:dissertation\&genre=dissertations+\%26+theses\& sid=ProQ:ProQuest+Dissertations+\%26+Theses+Globa

Giroux, G. (1991). An Analysis of Municipal Budget Variances. Accounting, Auditing \& Accountability Journal, 4(1), 29-50. https://doi.org/10.1108/09513579110003358

Haryani, E., \& Pranoto, T. (2012). A Proposed-Internal Audit Model for NGO in Indonesia (Study on Children Development Center-Salatiga Cluster). Journal of Arts, Science and Commerce, 3(3), 60-66. Retrieved from http://www.researchersworld.com/vol3/issue3/vol3_issue3_1/Paper_08.pdf

Hasanah, A. L. . (2019). Pengertian Microsoft Excel. Retrieved from https://www.advernesia.com/blog/microsoft-excel/microsoft-excel-adalah/

Lpdirect. (2019). Immunity from civil liability for directors, officers, or trustees - nonprofit corporations or nonprofit organizations,http://www.lpdirect.net/casb/crs/13-21115_7.html.

Mahirah, R., Djuwairiah, A., \& Sukirman. (2016). Designing Multiple Choice Test of Vocabulary for the First Semester Students At English Education Department of Alauddin State Islamic University of Makassar. ETERNAL (English, Teaching, Learning and Research Journal), 2(2), 194-208. https://doi.org/10.24252/eternal.v22.2016.a9

Munandar, M. (2001). Budgeting: perencanaan kerja pengkoordinasian kerja pengawasan kerja. Yogyakarta: BPFE.

Nasution, A. ., \& Prasetyawan, Y. (2008). Perencanaan Pengendalian Produksi. Yogyakarta: Graha IImu.

Parliament, E. (2018). Official Journal of the European Union,Https://eur-lex.europa.eu/legalcontent/EN/TXT/?uri=CELEX:32018R1139.

Physicscatalyst. (2019). The Phases of Teaching Online, https://physicscatalyst.com/graduation/phases-of-teaching/2019.

Roestel, M. Van. (2016). A Collaborative Approach to Budgeting and the Impact on the Budgeting Process: A Case Study. Dissertation of Walden University.

Said, H. b M., Baharudin, S. A., Izharuddin, A. F. B., Idris, B. I., \& Othman, B. H. (2019). Adoption of technology application among employees at workplace: A case of property development in Malaysia. International Journal of Innovation, Creativity and Change, 6(4), 338-359.

Savitri, E. (2018). Anggaran Bahan Baku. Https://Repository.Unri.Ac.Id/Xmlui/Bitstream/Handle/123456789/9138/BAB\%204\%20 ANGGARAN\%20BAHAN\%20BAKU, Diakses Tanggal 10 Maret 2019, 71-82.

Shields, J. F., \& Shields, M. D. (1998). Antecedents of participative budgeting. Accounting, Organizations and Society, 23(1), 49-76. https://doi.org/10.1016/S03613682(97)00014-7 
Stafnew. (2018). Microsoft

Excel,http://staffnew.uny.ac.id/upload/132161227/pengabdian/materi-ppmmicrosoftexcell.pdf.

Sulindawati, N., Suharsono, N., Lasmawan, W., Natajaya, N., \& Sunu, G. . (2019). The Implementation of a Village Financial Administration Teaching Model through Microsoft Excel Program. International Journal of Innovation, Creativity and Change. Www. ljicc.Net, 5(6), 19-34.

Sulindawati, N., Yudantara, I. G. A. P., \& Musmini, L. S. (2019). An Analysis of Learning Devices Need in Budget Reporting, 69(Teams 2018), 188-193. https://doi.org/10.2991/teams-18.2019.33

Suryanto, M. R., \& Sadjiarto, A. (2013). Efisiensi Penggunaan Model Eoq (Economic Order Quantity) Pada Pt. Puspa Madu Sari Salatiga. Jurnal IImiah Among Makarti, 5(10), 110-134.

Suryono, B. (2016). Organisasi Nirlaba: Karakterisitik Dan Pelaporan Keuangan Organisasi. EKUITAS (Jurnal Ekonomi Dan Keuangan), 59. https://doi.org/10.24034/j25485024.y1999.v3.i2.1883

Thi, O., Le, T., \& Mai, Q. (2020). Examining the technology acceptance model using cloudbased accounting software of Vietnamese enterprises, 10, 2781-2788. https://doi.org/10.5267/j.msl.2020.4.032

Thuya, N. Van. (2020). The adoption of the internet of things in Vietnam. International Journal of Innovation, Creativity and Change, 12(4), 22-35.

Undiksha. (2017). Pedoman Studi Program Sarjana dan Diploma Universitas Pendidikan Ganesha.

Venkatesh, V., Morris, M. G., Davis, G. B., \& Davis, F. D. (2003). User Acceptance Of Information Technology: Toward A Unified View. Mis Quarterly, 47(2), 252-269. https://doi.org/10.1006/mvre.1994.1019

Venkatesh, V., Thong, J. Y. L., \& Xu, X. (2012). Venkatesh_Thong_Xu_MISQ_forthcoming (Gender Age Experience). MIS Quarterly, 36(1), 157-178. Retrieved from https://pdfs.semanticscholar.org/6256/0e2001480fd1f22558ce4d34ac93776af3e6.pdf \%0Ahttps://pdfs.semanticscholar.org/6256/0e2001480fd1f22558ce4d34ac93776af3e6. pdf?_ga=2.124539978.1994179764.1540339706-2125081534.1540339706

Venkatesh, V., \& Zhang, X. (2010). Unified theory of acceptance and use of technology: U.S. vs. China. Journal of Global Information Technology Management, 13(1), 5-27. https://doi.org/10.1080/1097198X.2010.10856507

Westin, L., Sundler, A. ., \& Berglund, M. (2015). Students' experiences of learning in relation to didactic strategies during the first year of a nursing programme: a qualitative study.

Widyaningsih, S. W., Yusuf, I., Prasetyo, Z. K., \& Istiyono, E. (2020). Online Interactive Multimedia Oriented to HOTS through E-Learning on Physics Material about Electrical Circuit, 9(1), 1-14. https://doi.org/10.23887/jpi-undiksha.v9i1.17667

Wikipedia. (2013). Quantity Theory of Money. https://doi.org/10.4337/9781843768678.00139

Wikipedia. (2018). Organisasi Nirlaba. https://ld.Wikipedia.Org/Wiki/Organisasi_nirlaba. Retrieved from https://id.wikipedia.org/wiki/Organisasi_nirlaba

Wright, D. ., \& Nelsen, J. (2019). Cpetcm File:///E:/Artikel\%202019\%20b/classmeetings.pdf. 